\title{
МЕТОДОЛОГІЯ ПРАВА
}

УДК 340.12

doi: https://doi.org/10.33270/02201901.44

Бандура О. О. - доктор фрілософрських наук, профресор, профресор кафедри філософії права та юридичної логіки Національної академії внутрішніх справ, м. Київ

ORCID: https://orcid.org/0000-0002-8043-0988

\section{Праксеологія права як складова фрілософської праксеології (загальні аспекти)}

Mета статті полягає в тому, щоб привернути увагу сучасних учених у галузі фрілософрії права до праць української фрілософрської школи 1960-х років у галузі загальної фрілософії та фрілософрської праксеології, а також обгрунтувати, що низка положень праксеології права $\epsilon$ складовою відповідних положень фрілософрської праксеології, а діалектичні взаємозв'язки правової праксеології з правовими гносеологією, аксіологією, антропологією та онтологією зумовлені діалектичними взаємозв'язками фрілософрської праксеології із фрілософрськими гносеологією, аксіологією, антропологією та онтологією. Методологія. У cmaтmі використано передусім діалектичний і системно-структурний методи, методи логіки. Наукова новизна статті полягає в тому, що в ній увагу сучасних фрахівців із фрілософії права акцентовано на здобутках української фрілософрської школи 60-х років XX століття, оскільки їх доцільно поширити на фрілософрію права загалом і правову праксеологію зокрема. Органічні взаємозв'язки правової праксеології з іншими основними розділами фрілософрії права зумовлені наявністю органічних взаємозв'язків фрілософрської праксеології $з$ відповідними загальнофрілософрськими дисциплінами. Висновки. Правова діяльність утілює сутність людини як правової істоти, це субстанція ї̈ буття. Правова людина є абсолютно первинною фформою людського самобуття у сфрері права. У процесі правової діяльності відбувається розвиток суспільства й удосконалення правової людини. Пізнавальна діяльність є складовою правової діяльності спільно з практичною. Правова діяльність як суть правової людини є процесом їі розгортання й об'єктивування в правовій культурі. Фахівцям із фрілософрії права необхідно глибше дослідити спадщину українських фрілософрів-шістдесятників, а також діалектику правових праксеології, гносеології, аксіології, антропології та онтології.

Ключові слова: праксеологія права; фрілософська праксеологія; філософрія права; правова діяльність; мета; суб'єкт; об'єкт; засоби; результат; діалектика.

\section{Вступ}

Праксеологія права $є$ складовою філософської праксеології. Проблеми фрілософрської праксеології стали предметом досліджень для представників української фрілософрської школи 60-х років минулого століття. Чимало уваги їм приділяли О. Яценко (latsenko, 1977) та В. Іванов (Ivanov, 1977). Проблеми праксеології права нині досліджує чимало фахівців. Передусім слід назвати С. Гусарєва, який дає загальну картину юридичної діяльності (Husariev, 2005). Досить широке коло авторів вивчає різні аспекти діяльності людини. Зокрема, О. Павлишин і М. Дурдинець проводять історико-правовий аналіз й оцінюють перспективи правотворчої діяльності в Україні (Pavlyshyn, \& Durdynets, 2019). Н. Шаптала досліджує повноваження Конституційного Суду України як вагомий чинник його діяльності (Shaptala, 2019). О. Гвоздік досліджує логічні критерії достатності доказів як важливий чинник оцінювання зібраної доказової бази й раціоналізації процесу ії формування та гарантії обґрунтованості прийняття судових рішень, що має принципове значення для ефеекивної діяльності суду (Hvozdik, 2019). М. Локтіонов вивчає питання наукової діяльності на прикладі фрілософрської творчості О. О. Богданова (Loktionov, \& Bogdanov, 2018). Г. Джанда аналізує можливості праксеологічного підходу в професійній педагогічній діяльності (Dzhanda, 2019). Є. Сапогова розглядає питання про саморозвиток особистості як суб'єкта діяльності (Sapogova, 2019). У статті І. Швець формалізовано посткласичну модель суб'єкта діяльності відповідно до диференціальної онтології М. Деланда (Shvets, 2018). Б. Шевчик досліджує холотропний принцип праксеології 3 позицій аксіологічних наративів економічної діяльності (Shevchyk, 2018). В. Папп, О. Касинець та Г. Ольшаковська вивчають історію діяльності туристичних організацій (Papp, Kasynets, \& Olshakovska, 2018). Л. Кобилянська аналізує праксеологічні характеристики профресійної діяльності сучасного гувернера (Kobylianskaia, 2018). О. Павлишин, О. Кравчук та О. Лев вивчають питання ціннісних орієнтирів правової людини як суб'єкта правової діяльності (Pavlyshyn, Kravchuk, \& Lev, 2019). О. Мартенко та О. Павлишин аналізують питання про зв'язок свідомості як принципової характеристики суб'єкта діяльності з мисленням і мовою (Martenko, \& Pavlyshyn, 2019). В. Краєвський, О. Костенко, І. Головій, Г. Стригуненко, О. Пужайло та К. Вислоух розглядають аналіз і синтез як види діяльності (аналіз і синтез можна розуміти не тільки як методи пізнання, але і як методи 
діяльності, навіть як її види) (Kraievskyi, Kostenko, Holovii, \& Stryhunenko, 2019; Kraievskyi, Kostenko, Puzhailo, \& Vysloukh, 2019). Л. Герасіна розглядає методологію та праксеологію досліджень політичних процесів (Herasina, 2017). О. Топчій репрезентує провідні методологічні підходи праксеологічний, гносеологічний, онтологічний, аксіологічний - до вивчення питання про інформаційну безпеку неповнолітніх в адміністративному праві, але не враховує антропологічний підхід і не досліджує діалектичні зв'язки праксеологічного підходу з іншими підходами (Topchii, 2018). Зазначені автори практично не розглядають питання про зв'язок праксеології права 3 фрілософрською праксеологією, а також діалектичні зв'язки правової праксеології з іншими розділами фрілософрії права.

\section{Мета і завдання дослідження}

Мета статті - розглянути основні положення фрілософрської праксеології, викладені в працях українських фрілософрів-шістдесятників, їх значення для праксеології права, а також діалектичні зв'язки праксеології права з іншими філософрськоправовими дисциплінами.

\section{Виклад основного матеріалу}

Праксеологія права $є$ складником філософрської праксеології. Значний внесок у розвиток філософрської праксеології зробили представники української фрілософської школи $60-x$ років минулого століття. Їхні міркування та висновки $€$ вельми плідними для праксеології права. Найширше досліджували людську діяльність такі представники зазначеної школи, як О. Яценко (у монографії «Цілепокладання та ідеали» (latsenko, 1977)) та В. Іванов (у монографрії «Людська діяльність, пізнання, мистецтво» (Ivanov, 1977)).

Загалом однією з найважливіших категорій марксистської фрілософрії $\epsilon$ категорія практики. Марксизм можна тлумачити як фрілософрію практики й практично-творчого формування дійсності (Ivanov, 1977, р. 52). «Саме в практиці, зазначає В. Іванов, - марксизм відкрив єдине й загальне підґрунтя як реального людського життя, так і пізнання» (Ivanov, 1977, p. 53).

О. Яценко пише, що практика - «це матеріальне перетворення об'єктивно-реальних предметів з метою перетворення їх на умови життєдіяльності», що практична діяльність має предметно-чуттєвий характер і $€$ «дійсним способом людського буття» (latsenko, 1977, p. 11-12). Правову практику можна розуміти як спосіб правового буття.

Науковець вважає, що саме практика зумовила виникнення основного питання фрілософії: «Цей двоїстий характер людської практики як предметно-чуттєвої (матеріальної) та духовної діяльності, подвоєння людиною себе та свого світу у свідомості та завдяки свідомості в дійсності... $є$ реальною основою виникнення питання про відношення свідомості до буття» (latsenko, 1977, р. 13). Таким чином, можна вважати, що правова практика зумовила виникнення основного питання фрілософії права як питання про відношення правової людини й світу права, правосвідомості та правового буття.

Звернімось до такого міркування В. Іванова: «Усі різновиди духовної діяльності людей, зокрема й пізнання, з'явилися як універсально детерміновані суспільною практикою і такі, що по суті мають споріднену їй внутрішню структуру. Так був виявлений зв'язок між суб'єктом й об'єктом, людиною та світом, свідомістю і буттям, показана реальна єдність цих протилежностей» (Ivanov, 1977, p. 53). Адже, як підкреслює вчений, практика має усі чуттєві ознаки об'єктивної реальності та зрощена 3 матеріальними природними процесами, i одночасно постійно залишається похідною від людини, суб'єкта, її проявом і дійсністю; тому вона є єдністю суб'єкта й об'єкта, втілення їх взаємного переходу, їх реальної еквівалентності в одному (Ivanov, 1977, p. 54). На практиці дійсність можна прослідкувати як в ії̈ об'єктивних, так і в суб'єктивних вимірах і визначеностях, вона $€$ саме тим процесом, в якому дійсне формується і привласнюється як людське, а людське стверджується як суще (Ivanov, 1977, р. 54). Оскільки праксеологія права $€$ складовою фрілософської праксеології, в ній має бути справедливим положення про те, що у правовій практиці правову реальність можна бачити в її об'єктивних, суб'єктивних вимірах і визначеностях.

Далі в монографрії «Людська діяльність пізнання - мистецтво» В. Іванова читаємо: «Людина взагалі не має справи з іншою дійсністю, окрім даної їй практично, бо якщо вона ще і не перетворена речовим чином завдяки людській діяльності, вона навіть в людське споглядання входить тією мірою, якою опосередкована i зумовлена практикою. Тому практика утворює i зовнішній (споглядальний), і внутрішній (змістовний) горизонти людського відношення до світу, так що лише вона кожного разу дає також й останню відповідь на запитання, яким є світ сам по собі» (Ivanov, 1977, р. 55). Аналогічно можна сказати, що практична діяльність правової людини уможливлює ії розуміння світу права.

В. Іванов зазначає, що в другій половині $\mathrm{XX}$ ст. відбувалося колосальне розширення сфери людської практики та ї̈ потенційних можливостей, і воно зумовило актуальність загальнофрілософського поняття діяльності (Ivanov, 1977, p. 74). Він виокремлює в практиці категорію діяльності: «Хоча поняття «діяльність» 
існує давно і вживається для позначення найрізноманітніших взаємодій 3 огляду на їх активність, його зміст сприймався головним чином інтуїтивно і не міг претендувати на значення фрілософської категорії. Теоретична розробка цього поняття ... $\epsilon$, по суті, справою останнього часу, вона викликана кардинальними змінами практичних взаємозв'язків людини 3 дійсністю, і тому знадобився увесь досвід марксистського аналізу практики, щоб поняття діяльності вичленувало як загальне сутнісне визначення людини, субстанції її суспільного буття» (Ivanov, 1977, p. 59). В іншому місці він вказує, що категорія діяльності становить інтерес для фрілософії передусім як теоретична абстракція усієї практики людства в її історичній тенденції до перетворення природного світу на людський (Ivanov, 1977, р. 74).

$\mathrm{Ha}$ наш погляд, категорія діяльності $€$ ширшою, ніж категорія практики, оскільки вона охоплює як практичну діяльність, так і пізнавальну (хоча практична діяльність відіграє особливу роль у житті людства). Подібна ситуація наявна й у правовій сфері: правова діяльність - це і практична, і пізнавальна діяльність правників. Крім того, міркування В. Іванова цікаве ще й тим, що він вважає діяльність суттю людини. Подібно до цього можна сказати, що поняття правової діяльності містить загальне сутнісне визначення людини як правової істоти, субстанцію її буття.

Головна риса діяльності людини як homo sapiens полягає в тому, що вона має свідомий характер, і це безпосередньо відрізняє людину від тварини (Yatsenko, 1977, p. 9). О. Яценко акцентує на такій обставині: «Свідома діяльність людини у матеріальному світі можлива лише внаслідок того, що людина протистоїть природі не як щось зовнішнє, а як частина цієї ж самої природи» (latsenko, 1977, р. 87). Щодо правової діяльності, то слід сказати, що ії̈ можливість визначається належністю правової людини до світу права.

В. Іванов наголошує, що відношення діяльності як філософрської категорії та фрорм людської діяльності - це відношення «суть явище» (Ivanov, 1977, р. 69). На його думку, існування діяльності мислити як такої недопустимо, реальними слід визнавати тільки конкретні види діяльностей, що мають свій особливий предмет і спосіб (Ivanov, 1977, p. 79). Причому він зазначає, що і стосовно матерії не можна твердити, що вона існує як така, складаючись 3 єдиної властивості «бути об'єктивною реальністю». Таким чином він критикує ленінське визначення матерії як об'єктивної реальності. На його думку, в основі підходу Леніна до питання про матерію лежить непорозуміння, джерело якого - «в інтуїтивному прагненні онтологізувати абстракцію певної реальності, тобто представити її реальний зміст як автономне суще буття. Зрозуміло, що завжди виявляється «безживність» цього передбачуваного буття (що для абстракції цілком природно), а звідси й прагнення «оживити» його шляхом додавання до нього усього комплексу атрибутів, від яких воно раніше було абстраговане. Посилання на те, наприклад, що з самої по собі властивості бути об'єктивною реальністю не можна вивести ані руху, ані інших атрибутів матеріального світу, $\epsilon$ разючим симптомом розуміння предметного змісту людських абстракцій як чогось предметно сущого. По суті, у цій спробі «де абстрагувати» уявний зріз реального проявляється безглуздий протест проти самої природи абстрактного мислення та його особливих функцій» (Ivanov, 1977, р. 79).

Учений доходить такого висновку: «Матерія і $€$ зведеною в загальність, тобто в уявний предмет, ключову та граничну ознаку, що визначає суще щодо людської свідомості. Так само й діяльність $€$ граничною абстракцією суб'єкт-об'єктного відношення, тобто відношення людини до світу, в якій виражається всезагальний сенс продуктивного перетворення природного на людське» (Ivanov, 1977 , р. 79). Відповідним чином слід розуміти й категорію правової діяльності - вона є граничною абстракцією відношення людини як правової істоти до правової реальності, як сукупності правових норм та інститутів і правовідносин, і ця абстракція виражає загальний сенс перетворення правового сущого на правове належне.

В. Іванов розглядає такі форми діяльності, як перетворювальна, пізнавальна, ціннісноорієнтаційна, комунікативна та художня (Ivanov, 1977, р. 64-65). Ці форми має також правова діяльність, причому вони є складовими відповідних форм людської діяльності в загальному (фрілософському) розумінні.

Правова діяльність має таку саму структуру, як і діяльність загалом. До ії складу входять: суб'єкт, об'єкт, мета, умови, засоби, методи, сам процес діяльності та результат.

Суб'єктом діяльності загалом є людина як homo sapiens, вона має свідомий характер. О.Яценко пише: «Людська діяльність - це завжди й діяльність свідомості» (latsenko, 1977, р. 10). В. Іванов зазначає, що здатність бути людиною - це обов'язкова умова причетності індивідів до всіх видів діяльності. Суть людини, вважає він, це «не звичайна предметна суть, а діяльність в нескінченній сфері її предметних реалізацій» (Ivanov, 1977, p. 69-70). Філософшістдесятник підкреслює, що квінтесенцію «людського» становлять саме самоспричинення і самодіяльність» (Ivanov, 1977, р. 77). Діяльність, на його думку, і $€$ «процесом суб'єктивного спричинення, що не виводиться з чужорідних суб'єктові причин. I оскільки в силу цієї особливості вона $€$ абсолютно первинною 
формою людського самобуття, її природу можна осягнути не ззовні, а тільки з неї самої, шляхом теоретичного окреслення тих її визначеностей, які $€$ загальними опосередкуваннями людського відношення до сущого» (Ivanov, 1977, р. 77). Так само і суб'єктом правової діяльності $€$ правова людина, котра $є$ абсолютно первинною формою людського самобуття у сфері права.

Про можливість свідомої людської діяльності О. Яценко висловлюється так: «Свідома діяльність людини у матеріальному світі можлива лише внаслідок того, що людина протистоїть природі не як щось зовнішнє, а як частина цієї ж самої природи» (latsenko, 1977, р. 87). В. Іванов зазначає, що для діяльності характерна цікава своєрідність - суб'єкт, що пізнає її, одночасно $€$ й основним її агентом, навіть загальною передумовою її можливості (Ivanov, 1977, р. 78). Маємо підстави для аналогічного твердження, що діяльність людини у світі права можлива лише завдяки тому, що вона сама як правова істота $€$ частиною цього світу і що правова людина одночасно пізнає її та $€$ основним її агентом і навіть уможливлює саму правову діяльність.

Розмірковуючи про суб'єкт діяльності, В. Іванов зазначає, що «усе зовнішнє звернене до людини як її об'єкт (світ), відношення до якого і складає природу діяльності» (Ivanov, 1977, р. 77). Втім, можна додати, що діяльність людини може бути спрямована не лише на зовнішній світ, але й на внутрішній. Об'єктом правової діяльності $\epsilon$ суспільство, нормальне фрункціонування якого потребує цивілізованого регулювання. Крім того, правова діяльність спрямована і на сам суб'єкт, правову людину, яка повинна постійно вдосконалюватись.

Звернімося до питання про мету діяльності. Ї̈ наявність О.Яценко вважає «найбезпосереднішою характеристикою свідомості людини та ії способу буття»» (latsenko, 1977, р. 9). Зрозуміло, це стосується й правової діяльності - вона теж має свідомий, цілепокладальний характер. На думку О. Яценка, мета - це похідна від об'єктивної причинності та закономірності, вона детермінована об'єктивними законами, формується на підставі їх знання (latsenko, 1977, р. 83). «Зі свого боку, - пише він, - цілі є особливим рядом причин ідеальних причин людської діяльності» (latsenko, 1977, р. 83). Формування мети він розуміє як побудову ідеального уявлення про той предмет, явище, стан, до якого прагне людина; але одночасно, на його думку, це й «усвідомлення людиною своєї діяльності як цілеспрямованої, усвідомлення свого відношення як цільового» (latsenko, 1977, р. 75). Ці положення $€$ справедливими й для правової діяльності.

Мета правової діяльності полягає в упорядкуванні суспільного життя шляхом створення цивілізованих, гуманних і раціональних засобів розв'язання конфліктів, здатних дестабілізувати й навіть зруйнувати суспільство. Соціальний порядок перш за все визначається правовим порядком, верховенством закону.

Пильну увагу О. Яценко приділяє ідеалу як «уявному зразку досконалості, нормі, до якої слід прагнути як до кінцевої мети діяльності» і який «визначає спрямованість, спосіб і характер поведінки суб'єкта, котрий ним керується» (latsenko, 1977, р. 153). Суспільний ідеал він визначає як «уявлення про досконалий суспільний устрій, що забезпечує справжнє щастя людського життя, це зразок, до якого слід прагнути як до кінцевої мети» (Yatsenko, 1977, р. 154). На його думку, ідеал (нарівні з іншими духовними утвореннями) це «момент активнотворчого відображення дійсності»; вихідним моментом формування ідеалу для нього $\epsilon$ «усвідомлення суб'єктом своїх інтересів і відображення об'єктивної соціальної дійсності» (latsenko, 1977, р. 154). Це можна сказати й про ідеальне право, тобто про таке право, яке повною мірою забезпечує у суспільстві свободу, рівність та справедливість.

Ідеальне право - право, яке існує в ідеальній державі. Як відомо, ідеал за своєю природою $є$ недосяжним, принаймні, за наявних умов, він лише вказує напрямок, в якому слід рухатись; у дійсному житті суспільства можлива тільки часткова реалізація цих завдань. Стаття 1 Конституції України проголошує: «Україна $\epsilon$ суверенна і незалежна, демократична, соціальна, правова держава». Це ідеальна мета, правова держава у повному обсязі поки що не побудована в жодній країні світу, але наша держава повинна розвиватись саме в цьому напрямку. Тільки в такому разі вона зможе стати рівноправним членом спільноти цивілізованих держав світу. Рухаючись цим шляхом, вона зможе створити таке право, яке повніше забезпечуватиме у суспільному житті свободу, рівність і справедливість.

Перейдімо до питання про засоби діяльності. О. Яценко пише: «Людина визначає, які засоби їй необхідні для реалізації своєї мети, і створення цих засобів ставить собі за найближчу мету. У всякому розвиненому процесі праці засобом $€$ знаряддя, що $€$ вже продуктом попередньої доцільної діяльності. Воно заздалегідь піддавалося певній обробці, відповідно до природи кінцевої мети. Тому засіб, створений людиною, $є$ подвійним втіленням мети: по-перше, він $€$ матеріальним втіленням найближчої мети, по-друге, він потенційно у вигляді можливості несе в собі кінцеву мету. Зі створення засобів, таким чином, починається процес об'єктивізації мети» (latsenko, 1977, р. 90). На його думку, засіб може служити провідником мети тільки завдяки тому, 
що він діалектично з нею пов'язаний (latsenko, 1977, р.89). Засоби вчений розглядає як конкретний зміст тих об'єктивних можливостей, що відображаються у меті; засобами слугують тільки ті предмети, явища, які відповідають меті (latsenko, 1977, р. 90). Далі читаємо: «Ідеал є самоціллю діяльності, «ціллю цілей», що підпорядковує собі всі найближчі, проміжні цілі як засоби» (latsenko, 1977, р. 171). Реалізацію проміжних цілей він вважає «сходинками на шляху досягнення ідеалу» (latsenko, 1977, р. 165). Подібна ситуація існує й у правовій сорері.

3 позицій праксеології права цікавим є таке міркування О. Яценка: «Об'єктивними чинниками діяльності кожного нового індивіда $€$ вироблені раніше предмети, що стають предметами й засобами праці, а також ті соціальні форми, перш за все форми власності, в які вони втілюються. Всякому виробничому процесу, кожному виду діяльності вже подані матеріал і засіб праці, предмети індивідуального і виробничого споживання, що $\epsilon$ продуктами попередньої праці та в цьому сенсі втіленням суб'єктивного, але стосовно кожної нової діяльності - їі об'єктивними чинниками» (latsenko, 1977, р. 92).

У сфрері права напрацьовані раніше правові норми $€$ об'єктивними чинниками діяльності кожного нового індивіда, вони використовуються ним як засоби. Зокрема, майже в усьому світі посилено й розширено права та свободи людини і громадянина. Мабуть, найважливішим засобом у цьому процесі після права на життя $є$ право на свободу слова, тому що саме це право дозволяє захистити всі інші права. Юридичне закріплення права на свободу слова протягом дуже тривалого часу було метою прогресивних сил, і коли їі досягли, це право стало важливим засобом подальшого прогресивного розвитку права.

Засобами діяльності, на думку О. Яценка, у процесі діяльності стають також її об'єктивні умови. Саме суб'єктивний чинник діяльності, «приводячи об'єктивні чинники в доцільний рух, робить їх моментами людського буття, живими моментами людської діяльності» (latsenko, 1977, р. 91). Правова людина діє в певних умовах, і перетворює їх на засоби своєї діяльності.

Далі О. Яценко включає до кола засобів також спосіб, метод діяльності: «Загальне визначення категорії засобу можна дати наступне: засіб - це сукупність об'єктивних чинників і способу дій людини, що ведуть до досягнення мети. Вони можуть слугувати реалізації мети тому, що вони мають подвійну природу, це єдність об'єктивного і суб'єктивного» (latsenko, 1977, р. 89). В інших місцях він пише про залежність способу, методу дій як від засобів діяльності, так і від кінцевого результату, а також від предмета (latsenko, 1977, р. 83, 91). Ці міркування фрілософра-шістдесятника повністю справедливі й для сорери права.
На думку В. Іванова, суб’єкт у процесі діяльності виробляє спосіб і метод діяльності. Цей висновок вчений обґрунтовує тим, що взагалі головна риса діяльності полягає в їі здатності об'єктивувати саму себе: «Продуктивне об'єктивування взагалі складає невід'ємну й фундаментальну властивість діяльності, але якщо впродовж переважної частини історії акцент був на суб'єктивній своєрідності або на продукті діяльності, то тільки на останній історичній фазі стало... можливим приступити до практичного моделювання самої цієї діяльності. Останнє означає, що спосіб діяльності $€$ одним 3 їі продуктів» (Ivanov, 1977, р. 80). Відповідно й правознавці виробляють свої методи у процесі діяльності.

Рухаючись у річищі марксистського світогляду, українські фрілософии-шістдесятники основним видом діяльності вважали практику. Однак, «якщо виходити з того, що практика $€$ предметною взаємодією між суб'єктом і об'єктом, пише О.Яценко, - що людській діяльності наперед подані об'єктивні умови, то слід визнати, що для того, щоб успішно доцільно діяти 3 реальними предметами, треба знати їх властивості й закономірні зв'язки. Слід знати також соціальні умови своєї діяльності» (latsenko, 1977, р. 93). Далі він зазначає: «Пізнання і практика, відображення і творіння $€$ діалектично суперечливими моментами людського буття i конкретизацію більш загальної суперечності суб'єкт-об'єктного відношення. Як моменти того самого людського буття, пізнання (і ширше духовна діяльність взагалі) та практика $\epsilon$ не зовнішніми стосовно одне одного видами діяльності, але ії взаємопов'язаними, взаємозумовлювальними, взаємопронизуючими» (latsenko, 1977, p. 94).

У ссрері права практична діяльність також полягає у необхідності пізнання, пізнавальної діяльності, яка зі свого боку уможливлює раціональну правову практику. Правосвідомість втілюється в юридичних законах та правовідносинах.

В. Іванов акцентує на процесуальному характері діяльності як спрямованої активності суб'єкта (Ivanov, 1977, р. 60). Правова діяльність також є процесом. Дуже важлива риса процесу діяльності, за В. Івановим, полягає в тому, що вона приховує в собі механізм перетворення ідеального в матеріальне і навпаки (Ivanov, 1977, р. 61). У сорері права існує подібна ситуація: зміст правосвідомості втілюється у правову реальність, а правова реальність відображається у правосвідомості.

В. Іванов вважає, що «діяльність як суть людини нескінченно розгортається й об'єктивується у постійно оновлюваному світі "олюдненої предметності”, в тій реальності, яка називається 
суспільною культурою, взятою до того ж в ії історичному розвитку» (Ivanov, 1977, р. 82). Відповідно можна твердити, що правова діяльність як суть правової людини розгортається й об'єктивується в правовій культурі. Культура в найширшому значенні - це спосіб буття людини. Правова культура - спосіб буття людини як правової істоти, тобто створення правових норм (та інститутів) і регулювання за їх допомогою поведінки людей у суспільстві, суспільних відносин, перетворення останніх на правовідносини. Суть правової людини об'єктивується в зазначених нормах і відносинах.

Вчений переконаний, що тільки предметний історичний світ людської культури, який знаходиться в нескінченному процесі творення, еквівалентний природі діяльності, бо $є$ нічим іншим, як переходом діяльності в дійсність людського буття (Ivanov, 1977, р. 82). Предметний історичний світ правової культури еквівалентний природі правової діяльності, це перехід правової діяльності в дійсність правового буття.

Діяльність, зауважує цей представник української фрілософської школи, - «активність, яка за формою спрямована назовні, але змістовно завжди обернена на суб'єкт, і дорівнює йому, як взагалі людському суб'єктові» (Ivanov, 1977, р. 66). Таку саму картину спостерігаємо й у сорері права. У процесі діяльності розвивається й суб'єкт. «Потенції, закладені в людині ії природою, - пише О.Яценко, - стають людськими здібностями лише в процесі розвитку доцільної діяльності... Лише в діяльному опануванні природи і вже створеної предметної культури, в розпредметненні їх для себе і тим самим у визначенні своєї суті природною і соціальною предметністю формуються власне людські здібності, людські сутнісні сили» (latsenko, 1977, р. 99-100). На думку В. Іванова, «діяльність абсолютним чином замикає в собі дійсний зміст людини й людський зміст дійсності» (Ivanov, 1977, р. 63). Відповідно маємо підстави для твердження, що правова діяльність містить у собі дійсний зміст правової людини та людський зміст правової дійсності.

Звернімося до питання про місце загальної праксеології у системі філософських дисциплін (загальних гносеології, аксіології, антропології та онтології) і про місце праксеології права у системі філософсько-правових дисциплін (гносеології, аксіології, антропології та онтології права).

Діяльність людини поділяється на практичну та пізнавальну, тому філософська гносеологія входить до складу фрілософської праксеології, відношення між ними $є$ відношенням частини й цілого. Відповідно гносеологія права $є$ частиною праксеології права. Якщо звернутись до зв'язків фрілософської праксеології 3 фрілософрською аксіологією, то в цьому разі маємо подібну картину - остання $€$ складником філософської праксеології, оскільки цілі $€$ структурним елементом діяльності, i вони визначаються цінностями. Через це аксіологія права $є$ частиною праксеології права. Співвідношення фрілософської праксеології з фрілософрською антропологією має дещо інший характер. Остання $є$ цілим, а філософська праксеологія - частиною, тому що діяльність є однією (хоча і дуже важливою) 3 характеристик людини. Нарешті, фрілософрька праксеологія діалектично пов'язана й з фрілософрською онтологією. Буття знаходиться в процесі безперервного руху, і людська діяльність - один 3 різновидів цього руху; одночасно людина впливає на буття світу своєю діяльністю. Звичайно, ідеться передусім про творчу діяльність, яка дозволяє людині активно пристосовуватись до навколишнього світу й перетворювати його відповідно до своїх цілей. Правове буття створюється та розвивається людиною у процесі їі правової діяльності, і водночас актуальна правова діяльність здійснюється у просторі наявного правового буття, отже, залежить від нього. Це обумовлює існування органічних зв'язків між праксеологією права й онтологією права (Bandura, 2019, 58).

Таким чином, праксеологія права діалектично пов'язана з іншими субдисциплінами філософії права - правовими гносеологією, аксіологією, антропологією, онтологією. Вона $€$ необхідною складовою філософії права як єдиної діалектичної системи, оскільки фрілософська праксеологія - це органічна складова загальної фрілософії (яку також слід розуміти як єдину діалектичну систему).

\section{Наукова новизна}

Дослідження здобутків української фрілософрської школи 60-х років XX століття в галузі загальної фрілософії та філософської праксеології дають змогу глибше зрозуміти суть правової діяльності й самої людини як правової істоти. Категорія правової діяльності $€$ граничною абстракцією відношення людини як правової істоти до правової реальності, і ця абстракція виражає загальний сенс перетворення правового сущого на правове належне. Правова діяльність виражає суть людини як правової істоти, це субстанція її буття. Правова людина є абсолютно первинною формою людського самобуття у сорері права. У процесі правової діяльності розвивається суспільство та вдосконалюється сама правова людина. Правова діяльність як суть правової людини є процесом її розгортання й об'єктивування в правовій культурі. 


\section{Висновки}

Представники української фрілософрської школи 60-х років минулого століття зробили вагомий внесок у розвиток вітчизняної філософрії загалом і фрілософрської праксеології зокрема, їхні праці мають принципове значення для праксеології права. Вони дають підстави для таких висновків:

1. Категорія правової діяльності $€$ граничною абстракцією відношення людини як правової істоти до правової реальності як сукупності правових норм й інститутів і правовідносин, і ця абстракція виражає загальний сенс перетворення правового сущого на правове належне. Правова діяльність виражає суть людини як правової істоти, це субстанція ії буття. Правова діяльність має такі форми: перетворювальну, пізнавальну, ціннісно-орієнтаційну, комунікативну, художню.

2. Суб'єктом правової діяльності є людина як правова істота. Вона $€$ абсолютно первинною формою людського самобуття у сфері права. Об'єктом правової діяльності $€$ суспільство, нормальне функціонування якого потребує цивілізованого регулювання. Крім того, правова діяльність спрямована і на сам суб'єкт, правову людину, яка повинна постійно вдосконалюватись.

3. Правова людина, усвідомлюючи цілеспрямований характер своєї діяльності, починає її 3 визначення мети, котру можна розуміти як найвиразнішу характеристику правосвідомості та способу буття правової людини.

4. До кола засобів правової діяльності кожного нового індивіда входять передусім вироблені раніше правові норми, а також умови, в яких вона діє. Вони можуть слугувати реалізації мети тому, що вони мають подвійну природу, це єдність об'єктивного й суб'єктивного.

5. Правові пізнання та практика як складові правової діяльності тісно взаємопов'язані. Практична діяльність у сфрері права спричинює необхідність пізнання, відображення правової (і соціальної) реальності у правосвідомості, що зі свого боку уможливлює раціональну правову практику.

6. Правова діяльність як суть правової людини є процесом її розгортання й об'єктивування в правовій культурі. Правова культура спосіб буття людини як правової істоти, тобто створення правових норм (та інститутів) і регулювання завдяки їм суспільних відносин, перетворення останніх на правовідносини. Предметний історичний світ правової культури еквівалентний природі правової діяльності, це перехід правової діяльності в дійсність правового буття. Одночасно в процесі правової діяльності розвивається, вдосконалюється сама людина як правова істота.

7. Праксеологія права діалектично пов'язана 3 іншими субдисциплінами філософрії права правовими гносеологією, аксіологією, антропологією та онтологією, є органічною складовою фрілософрії права як єдиної діалектичної системи. Причина полягає в тому, що фрілософська праксеологія має діалектичні зв'язки з філософськими гносеологією, аксіологією, антропологією та онтологією, $є$ органічною складовою загальної фрілософрії (яку також слід розуміти як єдину діалектичну систему).

\section{REFERENCES}

Bandura, O.O. (2019). Hnoseolohiia prava yak skladova philosophskoi hnoseolohii [Gnoseology of Law as a Component of Philosophical Gnoseology]. Filosofski ta metodolohichni problemy prava, Philosophical and methodological problems of law, 2(18), 52-62. doi: https://doi.org/10.33270/02191802.52 [in Ukrainian].

Dzhanda, H.B. (2019). Potentsial prakseolohichnoho pidkhodu $v$ profesiinii pidhotovtsi maibutnikh uchyteliv pochatkovykh klasiv [The potential of a praxeological approach in the professional training of future primary school teachers]. Teoriia i metodyka profesiinoi osvity, Theory and methodology of professional education, 15(2), 63-67. doi: https://doi.org/10.32843/2663-6085- 2019-15-2-10 [in Ukrainian].

Herasina, L.M. (2017). Metodolohiia i prakseolohiia doslidzhen politychnykh protsesiv [Methodology and praxeology of political process research]. Visnyk natsionalnoho yurydychnoho universytetu imeni Yaroslava Mudroho, Bulletin of the National Law University Yaroslav the Wise, 2(33), 16-26. doi: https://doi.org/10.21564/2075-7190.33.109664 [in Ukrainian].

Husariev, S.D. (2005). Yurydychna diialnist: metodolohichni ta teoretychni aspekty [Legal activity: methodological and theoretical aspects]. Doctor's thesis. Kyiv: Znannia [in Ukrainian].

Hvozdik, O.I. (2019). Kryterii dostatnosti dokaziv [Evidence Sufficiency Criteria] Filosofski ta metodolohichni problemy prava, Philosophical and methodological problems of law, 2(18), 63-70. doi: https://doi.org/10.33270/02191802.63 [in Ukrainian].

latsenko, A.I. (1977). Tselepolaganie i idealy [Goal setting and ideals]. Kiev: Nauk. dumka [in Russian].

Ivanov, V.P. (1977). Chelovecheskaia deiatelnost - poznanie - iskusstvo [Human activity - cognition - art]. Kiev: Nauk. dumka [in Russian].

Kobylianskaia, L.I. (2018). Prakseologicheskie kharakteristiki professionalnoy deiatelnosti sovremennogo guvernera [Praxiological characteristics of the professional activities of a modern tutor]. Science and Education: a New Dimension. Pedagogy and Psychology, VI(65), 155, 32-35. doi: https://doi.org/10.31174/SEND-PP2018-155VI65-07 [in Russsian]. 
Kraievskyi, V.M., Kostenko, O.M., Holovii, I.S., \& Stryhunenko, H.I. (2019). Kontseptsii analizu i syntezu: suchasni suspilni zapyty i naukovi ta prykladni spromozhnosti [Concepts of analysis and synthesis: modern public requests and scientific and applied capabilities]. Mizhnarodnyi naukovyi zhurnal "Internauka", International scientific journal "Internauka", 10, 22-30. doi: https://doi.org/10.25313/2520-2294-2019-10-5282 [in Ukrainian].

Kraievskyi, V.M., Kostenko, O.M., Puzhailo, O.I., \& Vysloukh, K.D. (2019). Analiz i syntez yak vydy diianosti: metodolohiia konstruktsii ta prakseolohiia pryznachennia [Analysis and synthesis as types of activity: design methodology and destination praxiology]. Mizhnarodnyi naukovyi zhurnal "Internauka", International scientific journal "Internauka", 10, 5-21. doi: https://doi.org/10.25313/2520-2294-2019-10-5283 [in Ukrainian].

Loktionov, M.V., \& Bogdanov, A.A. (2018). Put ot monizma k tektologii [The path from monism to tectology]. Polilog/Polylogos, 2(4). doi: 10.18254/S0000065-3-1 [in Russian].

Martenko, O.L., \& Pavlyshyn, O.V. (2019). Vzaiemozviazok myslennia, svidomosti ta movy v kontseptsiiakh antychnykh myslyteliv [Interrelation of Thinking, Consciousness and Language in the Concepts of Ancient Thinkers]. Yurydychna psykholohiia, Legal Psychology, 2(25), 31-38. doi: https://doi.org/10.33270/03192502.31 [in Ukrainian].

Papp, V.V., Kasynets, O.V., \& Olshakovska, H.V. (2018). Rozvytok turystskoi prakseolohichnoi nauky [Development of tourist praxeological science]. Naukovyi visnyk Mukachivskoho derzhavnoho universytetu, Mukachevo State University Scientific Bulletin, 1(7), 41-45. doi: 10.31339/2413-3329-2018-1(7)-41-45 [in Ukrainian].

Pavlyshyn, O.V., \& Durdynets, M.Yu. (2019). Dvopalatnyi parlament yak forma demokratychnoi vlady v Ukraini: istorykopravovyi analiz i perspektyvy [Bicameral Parliament as a Form of Democratic Power in Ukraine: Historical and Legal Analysis and Prospects]. Filosofski ta metodolohichni problemy prava, Philosophical and Methodological Problems of Law, 1(17), 60-66. doi: https://doi.org/10.33270/01191702 [in Ukrainian].

Pavlyshyn, O.V., Kravchuk, O.V., \& Lev, O.R. (2019). Antropolohichno-pravovi vymiry profesiinoi deformatsii, moralnoi svidomosti pratsivnykiv Natsionalnoi politsii Ukrainy [Anthropological and Legal Measurements of Professional Deformation, Moral Consciousness of the National Police of Ukraine]. Filosofski ta metodolohichni problemy prava, Philosophical and Methodological Problems of Law, 2(18), 71-80. doi: https://doi.org/10.33270/02191802.71 [in Ukrainian].

Sapogova, E.E. (2019). Subektivnaia ontologiia i zniznennyy mir lichnosti [Subjective ontology and life world of personality]. Kulturno-istoricheskaia psikhologiia, Cultural and historical psychology, 15(1), 35-45. doi: 10.17759/chp.2019150104 [in Russian].

Shaptala, N.K. (2019). Konstytutsiinyi sudovyi protses: metodolohiia ta filosofsko-pravovi zasady [Constitutional Litigation: Methodology and Philosophical-Legal Foundations]. Filosofski ta metodolohichni problemy prava, Philosophical and methodological problems of law, 2(18), 8-17. doi: https://doi.org/10.33270/02191802.8 [in Ukrainian].

Shevchyk, B.M. (2018). Kliometryka ta kholotropnyi pryntsyp prakseolohii [Cliometrics and holotropic principle of praxeology]. Naukovyi visnyk Natsionalnoho lisotekhnichnoho universytetu Ukrayiny, Scientific Bulletin of National Forestry University of Ukraine, 28(4), 121-127. doi: 10.15421/40280423 [in Ukrainian].

Shvets, I.V. (2018). Prakseologicheskaia kontseptsiia subekta v sotsialnoy ontologii Manuelia Delanda [The praxeological concept of the subject in the social ontology of Manuel Delanda]. Sotsiodinamika, Sociodynamics, 3, 27-33. doi: 10.25136/2409-7144.2018.3.25730 [in Russian].

Topchii, O.V. (2018). Metodolohichni zasady doslidzhennia informatsinoi bezpeky nepovnolitnikh v administratyvnomu pravi [Methodological principles of the study of information security of minors in administrative law]. Administratyvne ta mytne pravo, Administrative and Customs Law, 2(21), 94-101. doi: https://doi.org/10.32836/2521-6473-2018-2-94-101 [in Ukrainian].

\section{СПИСОК ВИКОРИСТАНИХ ДЖЕРЕЛ}

Бандура О. О. Гносеологія права як складова філософської гносеології (загальні міркування). Філософрські та методологічні проблеми права. 2019. № 2 (18). С. 52-62. doi: https://doi.org/10.33270/02191802.52.

Джанда Г. Б. Потенціал праксеологічного підходу в професійній підготовці майбутніх учителів початкових класів. Теорія і методика профресійної освіти. 2019. Вип. 15. Т. 2. С. 63-67. doi: https://doi.org/10.32843/2663-60852019-15-2-10.

Герасіна Л. М. Методологія і праксеологія досліджень політичних процесів. Вісник національного юридичного університету імені Ярослава Мудрого. 2017. Т. 2. № 33. С. 16-26. (Серія «Філософія, фрілософрія права, політологія, соціологія»). doi: https://doi.org/10.21564/2075-7190.33.109664.

Гусарєв С. Д. Юридична діяльність: методологічні та теоретичні аспекти : дис. ... д-ра юрид. наук : 12.00.01. Київ : Знання, 2005. 375 с.

Гвоздік О.І. Критерії достатності доказів. Філософрські та методологічні проблеми права. 2019. № 2 (18). С. 63-70. doi: https://doi.org/10.33270/02191802.63.

Яценко А. И. Целеполагание и идеалы. Киев : Наук. думка, 1977. 275 с.

Иванов В. П. Человеческая деятельность - познание - искусство : монография. Киев : Наук. думка, 1977. 252 с.

Кобылянская Л.И. Праксеологические характеристики профессиональной деятельности современного гувернера. Science and Education: a New Dimension. Pedagogy and Psychology. 2018. VI (65). Issue: 155. C. 32-35. doi: https://doi.org/10.31174/SEND-PP2018-155VI65-07.

Краєвський В. М., Костенко О. М., Головій І. С., Стригуненко Г. І. Концепції аналізу і синтезу: сучасні суспільні запити й наукові та прикладні спроможності. Міжнародний науковий журнал «/нтернаука». 2019. № 10. С. 22-30. (Серія «Економічні науки»). doi: https://doi.org/10.25313/2520-2294-2019-10-5282. 
Краєвський В. М., Костенко О. М., Пужайло О. І., Вислоух К. Д. Аналіз і синтез як види діяльності: методологія конструкції та праксеологія призначення. Міжнародний науковий журнал «Інтернаука». 2019. № 10. C. 5-21. (Серія «Економічні науки»). doi: https://doi.org/10.25313/2520-2294-2019-10-5283.

Локтионов М. В., Богданов А. А. Путь от монизма к тектологии. Полилог/Polylogos. 2018. Т. $2 . \quad$ № 4. doi: $10.18254 /$ S0000065-3-1.

Мартенко О. Л., Павлишин О. В. Взаємозв'язок мислення, свідомості та мови в концепціях античних мислителів Юридична психологія. 2019. № 2 (25). С. 31-38. doi: https://doi.org/10.33270/03192502.31.

Папп В. В., Касинець О.В., Ольшаковська Г.В. Розвиток туристської праксеологічної науки. Науковий вісник Мукачівського державного університету. 2018. Вип. 1 (7). С. 41-45. doi: 10.31339/2413-3329-2018-1(7)-41-45.

Павлишин О. В., Дурдинець М. Ю. Двопалатний парламент як форма демократичної влади в Україні: історикоправовий аналіз і перспективи. Філософфські та методологічні проблеми права. 2019. № 1 (17). С. $60-66$. doi: https://doi.org/10.33270/01191702.

Павлишин О. В., Кравчук О.В., Лев О.Р. Антропологічно-правові виміри професійної деформації, моральної свідомості працівників Національної поліції України. Філософьські та методологічні проблеми права. 2019. № 2 (18). C. 71-80. doi: https://doi.org/10.33270/02191802.71.

Сапогова Е. Е. Субъективная онтология и жизненный мир личности. Культурно-историческая психология. 2019. T. 15. № 1. С. 35-45. doi: 10.17759/chp.2019150104.

Шаптала Н. К. Конституційний судовий процес: методологія та філософрсько-правові засади. Філософрські та методологічні проблеми права. 2019. № 2 (18). С. 8-17. doi: https://doi.org/10.33270/02191802.8.

Шевчик Б. М. Кліометрика та холотропний принцип праксеології. Науковий вісник Національного лісотехнічного університету України. 2018. Т. 28. № 4. С. 121-127. doi: 10.15421/40280423.

Швец И. В. Праксеологическая концепция субъекта в социальной онтологии Мануэля Деланда. Социодинамика. 2018. № 3. C. 27-33. doi: 10.25136/2409-7144.2018.3.25730.

Топчій О. В. Методологічні засади дослідження інформаційної безпеки неповнолітніх в адміністративному праві. Адміністративне та митне право. 2018. № 2 (21). С. 94-101. doi: https://doi.org/10.32836/2521-6473-20182-94-101.

Стаття надійшла до редколегії 01.04.2020

Bandura O. - Doctor of Philosophy, Professor; Professor of the Department of Philosophy of Law and Legal Logic of the National Academy of Internal Affairs, Kyiv, Ukraine

ORCID: https://orcid.org/0000-0002-8043-0988

\section{The Praxeology of Law as a Component of Philosophical Praxeology (General Aspects)}

The purpose of the article is to attract the attention of modern scientists in the sphere of philosophy of law to the works of the Ukrainian Philosophical School of the 1960s in the sphere of general philosophy and philosophical praxeology, as well as to show that a number of positions of the praxeology of law are the components of the relevant positions of philosophical praxeology and that the dialectical relations of legal praxeology with legal gnoseology, axiology, anthropology and ontology are caused by the dialectical relations of philosophical praxeology with philosophical gnoseology, axiology, anthropology and ontology. Methodology. Research methods are predetermined by nature of the research. The article uses primarily dialectical and system-structural methods, methods of logic. The scientific novelty of the article is to attract the attention of modern specialists in the philosophy of law to the achievements of the Ukrainian philosophical school of the 1960s, since they can and should be extended to the general philosophy of law and to legal praxeology in particular. Organic interrelations of legal praxeology with other major sections of the philosophy of law due to the presence of organic interrelations of philosophical praxeology with other major sections of general philosophy. Conclusions. Legal activity expresses the essence of man as a legal being, the substance of his being. The legal person is absolutely the primary form of human identity in the sphere of law. In the process of legal activity, society develops and the legal person itself improves. Legal activity as the essence of the legal person is the process of its deployment and objectification in the legal culture. Specialists in the philosophy of law need to study more deeply the heritage of Ukrainian philosophers of the sixties, as well as the dialectics of legal praxeology, gnoseology, axiology, anthropology and ontology.

Keywords: praxeology of law; philosophical praxeology; philosophy of law; legal activity; purpose; subject; object; means; result; dialectics. 